\title{
ENVIRONMENTAL STUDY TO IMPROVE THE PERFORMANCE OF GRAFTING MANGO SEEDLINGS USING DIFFERENT COVER MATERIALS FOR GREENHOUSES
}

Saleh, D.G.A. Hatem, M.H. ${ }^{(1)}$ Mostafa, E.A.M. ${ }^{(2)}$ and Kassim, F.S.E. ${ }^{(3)}$

\section{ABSTRACT}

This study was conducted during successive summer season of 2012 in the central laboratory for agricultural climate orchard, ministry of agriculture, at Dokki restrict, Giza governorate in Egypt. Due to the lack of appropriate environmental conditions for the success of the grafting process during the period of vegetative growth, this research aimed to study the effect of different greenhouse covering materials ( glass, polyethylene and white net (control)) and day times ( 8 AM, 1 PM and 6 PM ) for providing optimum conditions of environmental parameters (light intensity, air temperature and relative humidity) for successful grafting process on mango seedlings during development of vegetative growth as well as the interaction between these factors. The results of variance analysis showed that light intensity and ambient air temperature were recorded the highest average values $40.6^{\circ} \mathrm{C}$ and 46910 lux, respectively under polyethylene covering material at 1 PM. However, the lowest average values of air temperature and light intensity recorded $26.5^{\circ} \mathrm{C}$ and 1666 Lux under white net and glass covering materials, respectively. In contrast, the relative humidity $(R H)$ is decreased to reach $31 \%$ with polyethylene covering material. Stem length and leaf area recorded the greatest average values $21.7 \mathrm{~cm}$ and $249.8 \mathrm{~cm}^{2}$, respectively under glass covering material. Stem diameter and number of leaves recorded the greatest average values $0.89 \mathrm{~cm}$ and 19.5 leaves under polyethylene covering material. White net (control) recorded the lowest average values in stem length, diameter, leaf area and number were $14 \mathrm{~cm}, 0.66 \mathrm{~cm}, 219.6 \mathrm{~cm}^{2}$ and 15.9 leaves, respectively.

\footnotetext{
(1) Prof., Ag. Eng. Dept., Fac. of Agric., Cairo University

(2) Assistant. Prof., Ag. Eng. Dept., Fac. of Agric., Cairo University

${ }^{(3)}$ Prof., Hort. Res. Inst., Agric. Research Center
} 
Polyethylene covering material led to positive impacts on the vegetative growth and developed of grafted mango seedlings during this season.

Keywords : Cover Material, White net, Polyethylene, Glass, Mango, Grafting

\section{INTRODUCTION}

reenhouses are used in order to create a more favorable
environment that is essential for plant growth and productivity,
especially in an arid regions and hot summers such as Arab Republic of Egypt. A greenhouse allows plants to grow during any season of the year by controlling light intensity, air temperature, moisture levels, and carbon dioxide. The greenhouses are usually covered with a material (i.e., glass or plastic) that have the ability to transmit light that provides essential energy for plant growth and production.

In Egypt, numbers of greenhouses reached 61817 greenhouses with area reached 4850.68 feddans, according to Agriculture Directorates of governorates, Economic and statistics Affairs Sector, 2013 year, this area concentrated in lower and middle Egypt, and inside and outside the valley.

The greenhouse climate also depends on the external weather conditions. Apart from solar radiation, the most important external disturbances are outside air temperature, moisture content, and wind speed. Wind speed influences the heat exchange coefficient of the wall and cover and also affects the ventilation rate through openings in the cover. According to Smith (1984), ventilator area as percentage of total floor area should be about $16 \%$ in natural ventilation.

Okyereh (2009) sited that temperature affects the normal growth of crops. High temperatures during the day cause great loss of water through the process of evapotranspiration which increases with increasing temperature. High night temperatures can affect crop yield. Light energy is also very essential for the manufacturing of plant's food. Apart from photosynthesis, light intensity influences the rate of plant growth and development. Humidity alters the rate of evapotranspiration. Under low humidity, plant loses a lot of water to the atmosphere. Evaporation and transpiration decrease with increase in relative humidity but increase with decrease in relative humidity, Tweneboah (2000). 
The influence of light intensity on the productivity of plant differs depending on whether one is considering a plastic-house crop during the low light conditions or a field of plant growing in full sun. Light penetrates transparent glass or Polyethylene, and the spectral distribution of light will differ with the different type of materials Mortensen and Stromme (1987).

The choice of covering materials is strongly dependent upon several factors i.e. solar radiation transmission, long wavelength radiation transmission, resulting amount of diffuse solar radiation under the cover, resistance to ultraviolet (UV) degradation, mechanical strength, coefficient of expansion, temperature limitations, heat losses, initial purchase price and installation cost, Godbey et al (1979).

Fuchs et al. (2006) mention that the cover material of a greenhouse reduces solar radiation transmission by about $30 \%$ and which has a ventilation near 30 volume changes per hour, transpiration can cool foliage and air below outside air temperature.

Rosa et al. (1989) reported that, the solar irradiation inside the greenhouse depends strongly upon its orientation. A greenhouse with its longitudinal axis aligned along the North-South direction collects more radiation in summer and less in winter as compared with a greenhouse with its axis aligned along the East-West direction. The collection is more uniform throughout the year in a greenhouse with its axis aligned along the East-West direction.

Mango is a very popular and traditional fruit in Egypt. It is grown commercially in 23 of the 27 governorates. Some of the mango orchards are about 150 years old. Cultivated area, yield, and total production have increased steadily in the last few years.

Egypt is considered one of the major mango producing countries in Africa. It produces a huge tonnage of mango fruits. However, a small percentage of the production is primally exported to regional markets Al massry, (2002) .

The total acreage of mango in Egypt reached 241101 feddans producing about 712537 tons with an average of 3.547 tons /fed according to the Agricultural Census of the Ministry of Agriculture, 2013 year, these area is concentrated in Ismailia, Sharkkia, Giza, Nubaria and Fayoum 
Gover-norates. Sallanon (2013) mentioned that mango is a fruit of major economic importance produced throughout tropical and subtropical countries. Mangoes generally grow in warm climates $\left(25-35{ }^{\circ} \mathrm{C}\right)$ and fruit may sometimes be exposed to temperatures of above $35{ }^{\circ} \mathrm{C}$, as well as to high irradiance. Moreover, fruits within a mango tree are exposed to a wide range of temperature and light conditions due to their position in the canopy and to its shape, which will vary depending on the cultivar and the pruning techniques used, Shaban (1996).

Grafting process is one of the agricultural operations which should be concerned by the environmental studies because of its importance in the process of vegetative propagation which is the only way to give a large number of offspring in the varieties of seeds only fetus while maintaining the distinctive characteristics Al massry, (2002). Grafting should be done in the warmest months of the year with night temperatures above $18^{\circ} \mathrm{C}$ $\left(64^{\circ} \mathrm{F}\right)$. Many grafting methods are successful with mango, including cleft grafting, chip budding and whip grafting Al-Nasharty (1964) .

It is also the most important reasons for the failure of grafting process is that appropriate environmental conditions of temperature and humidity isn't available during and after grafting process . Toumi, (1997) found that the most suitable air temperature for the formation of tissue callus in the area of fusion between the original and the scion ranged $(21-24)^{\circ} \mathrm{c}$, this explained that there was low grafting process success when conducted in summer due to high air temperature and low relative humidity, as it should provide adequate air temperature and relative humidity around the docking area so as not to dry baits by connecting the region with wax Albaran.

This research trends to graft the seedlings of mango, due to its exposure to certain inappropriate climatic conditions of ( air temperature, strong wind and solar radiation ) which face by producers in the open field during the period of grafting and growth stage after grafting which affects the growth of plants. Also, the mango is a tropical fruits do not bear high temperature in summer, which affects on the success rate of grafting Hartmann (1997). Therefore, the aim of this investigation is studying the effect of three different greenhouse covering materials to 
improve the performance of grafted mango seedlings under greenhouses conditions in Egypt.

\section{MATERIALS AND METHODS}

This study was conducted in the central laboratory for agriculture climate orchard , ministry of agriculture , Giza in Egypt, (Latitude $30.06^{\circ} \mathrm{N}$, and Longitude $31.25^{\circ} \mathrm{E}$ ) with constant orientation North-South for all greenhouses. The study was carried out during summer 2012 from June to August period.

\subsection{Experimental greenhouses description}

The statistical design used the Complete Randomize Design (CRD) coupled with Duncan's multiple range tests for the means separation test where it used two factors, grafting time and greenhouse covering material according to Snedecor and Cochran, (1989). According to the two factors completely randomized design, the interaction of three greenhouse covering materials have been used. The covering materials are white net with $60 \%$ shade as control, 200 micron polyethylene plastic sheet thickness, and 5 millimeter glass thickness. The ambient air temperature, relative humidity and light intensity were measured regularly.

Agriculture practices for the seedlings in the three greenhouses were the same for irrigation which was added manually as three liters of water per seedling for three days per week and fertilization were used $\mathrm{N}: \mathrm{P}: \mathrm{K}$ at 19:19:19 ratio where doses were 1 gm/litre Ammonium nitrate, 1gm/1 potassium sulfate and $3 \mathrm{gm} / 1$ superphosphate as well as Trace elements Fe , $\mathrm{Zn}$ and $\mathrm{Mg}$ representing 2gm/10 litre for each. Mango seedlings were grown in soil mixture consisted of clay: Loam: sand as 1:1:1 ratio, respectively in black plastic bags $(14 \mathrm{~cm}$ diameter and $20 \mathrm{~cm}$ height). The cultivated area was 10 seedlings per square meter.

\subsection{Environmental measurements}

Three replications air temperature, relative humidity and light intensity were measured in each greenhouse monthly during the summer season, at 
three different positions on $1 \mathrm{~m}$ height, the measurements were done 3 times per day at 8:00 AM , 1:00 PM and 6:00 PM .

The light intensity has been measured using A portable illumination Luxmeter (Model FMC- 10M : ins DX-200) figure 1, while the ambient air temperature and relative humidity were measured continuously by using a digital Thermo-hygrometer (model Art. No. 30-5000/30-5002) in the three parts of each of the three green houses figure 2 . The digital Thermo-hygrometer was calibrated every four days against mercury thermometer and a reference hygrometer before the start of season.
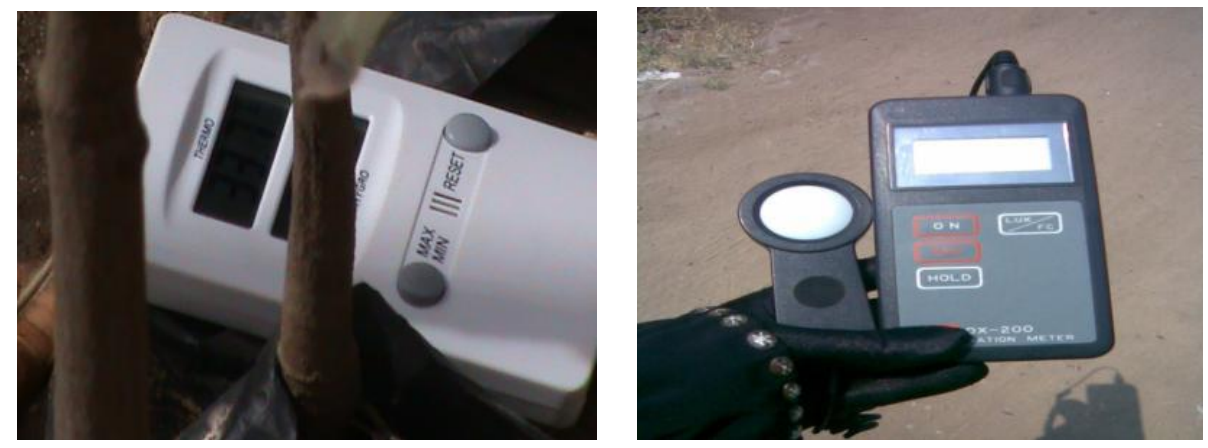

Fig (1) : Portab Lux- Meter Fig (2) Digital Thermo-hygrometer

\subsection{Vegetative measurements}

Vegetative measurements were recorded monthly for six successive months after grafting. Twenty scions of Keitt mango cultivar for each greenhouse were taken from true-to-type trees. Defoliated scions aged 12 month old at average length of $10-15 \mathrm{~cm}$ were used. The scion of the mango cultivar ( Keitt ) was grafted by using top cleft grafting method onto homogenous vegetative seedlings rootstock which obtained in the present study in summer (June) of 2012 season.

The rootstock aged 12 months old in summer grafting. The scion and grafting region were completely tied with transparent polyethylene tapes to prevent the scion of drought and maintains humidity around the scions. Scions length $(\mathrm{cm})$, diameter $(\mathrm{cm})$ above grafting union by using Vernier Caliper, figure 3. Area of leaf per seedling by using a Portable area meter : model Li - 3000 figure 4. Number of leaves per shoot above grafting union has been counted. 


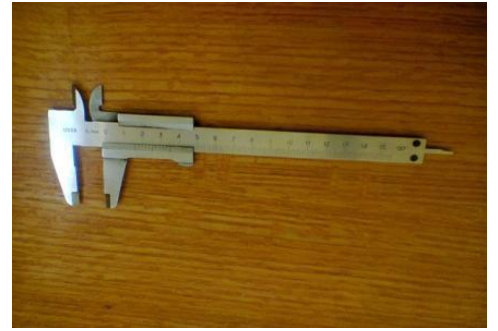

Fig (3) : Vernier Caliper

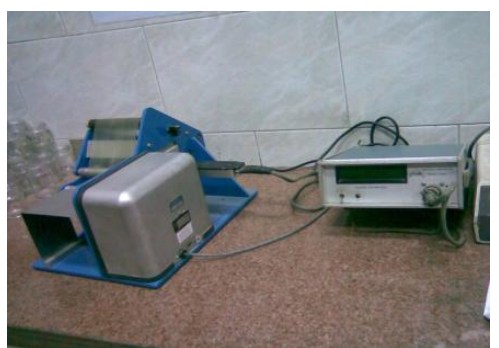

Fig (4) : Portable Area Meter

\section{RESULTS AND DISCUSSION}

\subsection{Environmental parameters}

\subsubsection{Effect of day times and greenhouse covering materials on light intensity}

The results of variance analysis showed that the greatest value for light intensity was 46910 Lux under polyethylene covering material at day time at $1 \mathrm{PM}$ and the lowest average value was 1666 Lux under glass covering material as shown in table 1 . This results agreed with Papadopoulos (1997) concerning to the light intensity value which was the highest value in polyethylene houses, and the lowest value in glass house.

Table 1: Effect of day times and covers on light intensity, lux.

\begin{tabular}{cccc} 
& \multicolumn{3}{c}{ ( Light Intensity, Lux ) } \\
Treatment & at 8 AM & at 1 PM & at 6 PM \\
\hline Glass cover & $7167 \mathrm{f}$ & $38580 \mathrm{c}$ & $1666 \mathrm{~g}$ \\
White net cover & $8678 \mathrm{e}$ & $43510 \mathrm{~b}$ & $2322 \mathrm{~g}$ \\
Polyethylene cover & $12811 \mathrm{~d}$ & $46910 \mathrm{a}$ & $2486 \mathrm{~g}$ \\
\hline
\end{tabular}

Note: Means in the same column (d) followed by the same letters are not significantly different except the other columns have significant differences $(\mathrm{P}<0.05)$, and LSD $=$ 867.2 according to Duncan's Multiple Range Test (DMRT).

Similar results with Hashem (2011) who reported that the highest average light intensity was observed under polyethylene sheet followed by white net cover. Also, Mortensen and Stromme (1987) mentioned 
that light penetrates transparent glass or Polyethylene, and the spectral distribution of light will differ with the different type of materials.

\subsubsection{Effect of day times and covering materials on air temperature}

Results of variance analysis showed that there are a significant differences between daytimes and covering materials for averages values of air temperature. Noticeable that the greatest average value of air temperature recorded $40.7{ }^{\circ} \mathrm{C}$ at $1 \mathrm{pm}$ under polyethylene covering material and the lowest average value of air temperature recorded $26.5^{\circ} \mathrm{C}$ at $6 \mathrm{pm}$ under white net covering (control) as presented in table 2 .

\section{Table 2 : Effect of day times and covers on air temperature, ${ }^{\circ} \mathrm{C}$}

(Air temperature,${ }^{\circ} \mathrm{C}$ )

\begin{tabular}{cccc} 
Treatment & At 8:00AM & At 1:00 PM & At 6:00PM \\
\hline Glass cover & $31.6 \mathrm{f}$ & $37.8 \mathrm{~b}$ & $31.2 \mathrm{~g}$ \\
White net cover & $28.6 \mathrm{~h}$ & $35.9 \mathrm{c}$ & $26.5 \mathrm{i}$ \\
Polyethylene cover & $33.3 \mathrm{e}$ & $40.7 \mathrm{a}$ & $34.9 \mathrm{~d}$ \\
\hline
\end{tabular}

Note: Means in all columns followed by the different letters are significantly different $(\mathrm{P}<0.05)$, and LSD $=0.332$ according to Duncan's Multiple Range Test (DMRT).

Similar results were reported with Nakasone and Paull., (1999) that the air temperature in the range of $\left(24^{\circ} \mathrm{C}-30{ }^{\circ} \mathrm{C}\right)$ is needed and the mango tree can endure up to $48{ }^{\circ} \mathrm{C}$ during fruit development if sufficient irrigation is available. The tree readily grows in all the tropic and subtropic climates with a mean temperature of $21^{\circ} \mathrm{C}$ to $27{ }^{\circ} \mathrm{C}$. Whereas, Opeke (1992) mentioned that the lowest temperatures tolerated by mango are $1{ }^{\circ} \mathrm{C}$ to $2{ }^{\circ} \mathrm{C}$. While, NDA (2000) decided that the mango trees also survive in a temperature as high as $45^{\circ} \mathrm{C}$.

Similar results were reported with Papadopoulos (1997) that the average air temperature in polyethylene houses was higher than in glass houses although day and night temperature set points were the same .

Hashem et al (2011) mentioned that the highest value of maximum air temperature was observed under polyethylene sheet cover treatment followed by white net, while the lowest values were observed in open filed. Polyethylene cover induced the highest temperature during the 
whole season, similar results were reported by Hashem et al.(2011) found a moderate decrease in temperatures associated with the use of nets at the spring season.

\subsubsection{Effect of day times and covering materials on relative humidity}

Results of variance analysis showed that the three times were similar where the greatest average value of relative humidity recorded $60 \%$ under white net (control) covering material while the lowest average value was $31 \%$ under polyethylene covering material as shown in table 3 These results were in line with those reported by El-Abd et al (1994), indicating a 2-6\% increase in relative humidity associated with the use of nets. The same authors also reported a decrease in evaporation associated with the use of nets and a significant reduction in wind speed. . While, Medany et al (2009) mentioned that at lower wind speed, which was true under present conditions, mainly the buoyancy effect contributes in ventilation. Whereas, Campen and Bot (2003) explained the ventilation phenomenon. The pressure difference over the openings was one of the driving forces for ventilation, which could be either due to the wind outside the greenhouse or due to the temperature difference over the openings. At lower wind speed, which was true under present case, mainly the buoyancy effect contributes in ventilation.

Table 3 : Effect of day times and covers on relative humidity, \% .

(Relative Humidity, \%)

\begin{tabular}{cccc} 
Treatment & At 8:00AM & At 1:00 PM & At 6:00PM \\
\hline Glass cover & $54 \mathrm{~b}$ & $35 \mathrm{e}$ & $47 \mathrm{c}$ \\
White net cover & $60 \mathrm{a}$ & $43 \mathrm{~d}$ & $55 \mathrm{~b}$ \\
Polyethylene cover & $43 \mathrm{~d}$ & $31 \mathrm{f}$ & $35 \mathrm{e}$ \\
\hline
\end{tabular}

Note: Means in all columns followed by the different letters are significantly different $(\mathrm{P}<0.05)$, and LSD $=1.64$ according to Duncan's Multiple Range Test (DMRT).

\subsection{Vegetation parameters}

Results of variance showed that there are significant differences between different covering materials for the vegetative parameters as presented in table 4. Experimental vegetative parameters recorded the highest average values under polyethylene covering materials while recorded the lowest average values under the white net (control) covering materials.

The highest average values of stem length and diameter recorded 21.7 and $0.89 \mathrm{~cm}$ under glass and polyethylene covering materials, 
respectively. However, the lowest average values of stem length and diameter recorded 14 and $0.66 \mathrm{~cm}$, respectively under white net (control) covering material. While, the highest average values of leaf area and number recorded $249.8 \mathrm{~cm} 2$ and 19.5 leaves under glass and polyethylene covering materials, respectively. However, the lowest average values of leaf area and number recorded $219.6 \mathrm{~cm} 2$ and 15.9 leaves, respectively under white net (control) covering material.

Table 4 : Plant growth and development under the experimental cover materials in summer season.

Parameters*

\begin{tabular}{lllll}
\hline Treatments & $\begin{array}{l}\text { Stem length, } \\
\text { cm }\end{array}$ & $\begin{array}{l}\text { Stem diameter, } \\
\text { cm }\end{array}$ & $\begin{array}{l}\text { Leaf area, } \\
\mathbf{c m} 2\end{array}$ & $\begin{array}{l}\text { Leaf } \\
\text { number }\end{array}$ \\
\hline Glass & $21.7 \mathrm{a}$ & $0.7 \mathrm{~b}$ & $249.8 \mathrm{a}$ & $16.0 \mathrm{~b}$ \\
White net & $14 \mathrm{~b}$ & $0.66 \mathrm{~b}$ & $219.6 \mathrm{~b}$ & $15.9 \mathrm{~b}$ \\
Polyethylene & $19.4 \mathrm{a}$ & $0.89 \mathrm{a}$ & $238.3 \mathrm{a}$ & $19.5 \mathrm{a}$ \\
\hline LSD Value & 2.538 & 0.1835 & 11.12 & 2.129 \\
\hline P & $<0.05$ & $<0.05$ & $<0.05$ & $<0.05$ \\
\hline
\end{tabular}

*Stem length and diameter, leaf area and leaf number per seedling were measured after six months of grafting on june.16. 2013 : means presented are average of 10 observations in each of three greenhouses. Different letters in the same column indicate significant difference $(\mathrm{P}<0.05)$, according to Duncan's Multiple Range Test.

Using the polyethylene covering material led to positive impacts on the vegetative growth and developed of grafted mango seedlings during this season. These results is coincided with Papadopoulos., (1997) who reported that the plants in the polyethylene houses grew faster than the plants in glass houses.

\section{CONCLUSIONS}

Generally, the obtained results of the present research work declared that:

1. There were a significant differences in air temperature, relative humidity and light intensity during different covering materials and day times.

2. Air temperature and light intensity recorded the greatest average values $40.7^{\circ} \mathrm{C}$ and 46910 Lux, respectively under polyethylene covering material at $1 \mathrm{PM}$. However, the lowest average values 
recorded $26.5^{\circ} \mathrm{C}$ and $1666 \mathrm{Lux}$ under white net (control) and glass covering materials, respectively at $6 \mathrm{PM}$.

3. Relative humidity recorded the greatest average values $60 \%$ under white net (control) at $8 \mathrm{AM}$. While, the lowest average values recorded $31 \%$ under polyethylene covering material at $1 \mathrm{PM}$.

4. Stem length and leaf area recorded the greatest average values 21.7 $\mathrm{cm}$ and $249.8 \mathrm{~cm} 2$, respectively under glass covering material.

5. Stem diameter and number of leaves recorded the greatest average values $0.89 \mathrm{~cm}$ and 19.5 leaves under polyethylene covering material.

6. White net (control) recorded the lowest average values of vegetative parameters $14 \mathrm{~cm}, 0.66 \mathrm{~cm}, 219.6 \mathrm{~cm} 2$ and 15.9 leaves in stem length and diameter and leaf area and number, respectively.

7. Polyethylene covering material led to positive impacts on the vegetative growth and developed of grafted mango seedlings during this season.

\section{RECOMMENDATIONS}

On the basis of the conclusions, we can recommend that this experimental study was very effective for providing optimum conditions for successful grafting process on mango seedlings during development of vegetative growth and under different greenhouse cover materials. Noticeable that light intensity was very high in polyethylene house so plastic houses need to shade to protect plant against intensive light and high temperature injuries. So , the white net house should be used with Polyethylene house to give the well performance results. Also, It may be used other different cover materials with an experimental greenhouses to give the best favorable results.

As well as, other different plants may be used on the same experimental conditions. These points are possible to be taken into account as a result of the different greenhouse cover materials effect on air temperature , relative humidity and light intensity.

\section{REFERENCES}

\subsection{English References}

Campen, J. B. and Bot, G.P.A. (2003). Determination of green-housespecific aspects of ventilation using three-dimensional computational fluid dynamics. Biosys. Eng., 84:69-77. 
El-Abd, M. T. G. , Shanan, S.A., Abou- Hadid, A.F. and Saleh, M.M. (1994). Effect of different shading densities on growth and yield of tomato and cucumber plants. Egypt. J. Hort., 21:65-80.

Fuchs, M. , Dayan, E. and Presnov, E. (2006). Evaporative cooling of a ventilated greenhouse rose crop. Agriculture and Forest Meteorology, 138 (1-4): 203-215.

Godbey, L.C. , Dond, T.E. and Zornig, H. F. (1979) .Transmission of solar and long-wavelength energy by materials used as covers for solar collectors and greenhouses. Transactions of the ASAE, J. Heat transfer, 98:189 - 193.

Hashem, F.A. , Medany, M. A. , Abd El-Moniem, E.M and Abdallah, M.M.F. (2011). Influence of green-house cover on potential evapotranspiration and cucumber water requirements. Arab Univ. J. Agric. Sci., 19(1).

Hartman, H.T. (1997). Plant Propagation, Principles and Practices, Prentice Hall, Sixth Edition.

Medany, M.A. , Hassanein, M.K. and Farag, A.A. (2009). Effect of black and white nets as alternative cover to grown pepper under greenhouse. Acta Hort., 807.

Mortensen, L.M. and E. Stromme, (1987). Effects of light quality on some greenhouse crops. Scientia Hort. (Amsterdam), 33: 27-36.

National Department of Agriculture (2000). Cultivation of Mango Resource Centre, Directorate Communication,Pretoria South Africa Cited 20 October,2008 from http://www.nda.agric.za/publications

Okyereh, S.K. (2009). The determination of crop water requirement of mango in the transitional zone of Ghana. Master of science in soil and water engineering, faculty of mechanical and agricultural engineering , Kwame Nkrumah University of Science and Technology, March 2009 .

Papadopoulos, A.P. and Hao, X. (1997). Effects of greenhouse covers on seedless cucumber growth, productivity, and energy use. Scientia Horticulture 68 (1997) 113-123 .

Rosa, R. , Silva, A.M. and Miguel, A. (1989). Solar irradiation inside a single span greenhouse. Journal of Agricultural Engineering,43 :221 - 229 . 
Sallanon, H. (2013). Response of the physiological parameters of mango fruit (transpiration, water relations and antioxidant system) to its light and temperature environment. Journal of Plant Physiology 170 (2013) 567- 576.

Shaban, A.S.A. (1996). Factors Affecting Success of Grafting in Mango. M.S. Thesis. Fac, Agric. Cairo Univ.

Smith, I.E. (1984). Shading effects on greenhouse tomatoes and cucumbers. Acta Hort., 148: 491-500.

Snedecor, G.W. and Cochran, W.G. (1989). Statistical Methods. The lowa state unive. Press Amer. U.S.A. 8th Ed.

Tweneboah, C.K. (2000). Modern Agriculture in the Tropics with special reference to Ghanaian Food Crop. Co-Publisher, Ghana.

\subsection{Arabic References}

أحمد حامد النشرتى ، محمد عبد القادر الشيت. (9 9V ( I ) ـ تطعيم المانجو ، وزارة الزر اعة. المصري ، حمدي محمد (2002 ) - زراعة و إنتاج المانجو - معهد بحوث البساتين - مركز

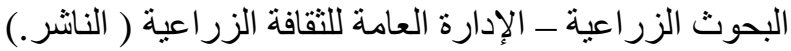

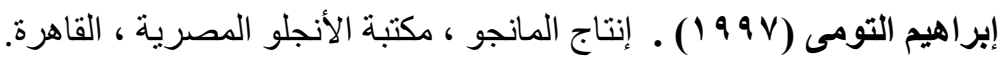

الملخص العربيى

\section{دراسة بيئية لتحسين آداء تطعيم شتّلات المانجو بإستخدام مواد غطاء مختلفة} للصوب الزراعية

دعاء جلال عباس صالح محمد هاثم حاتم(') إيهاب عبدالمنعم مجدى مصطفى(') فريل سعد عيد قاسم(")

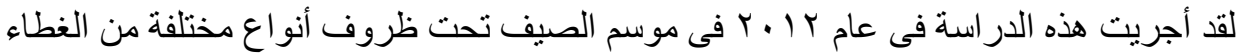

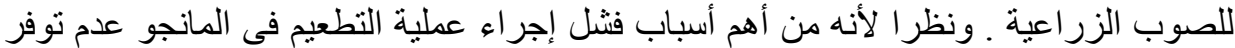

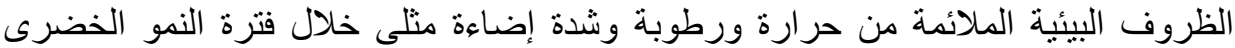

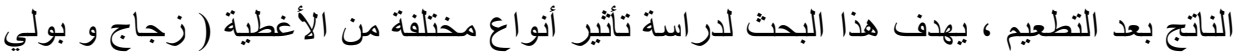

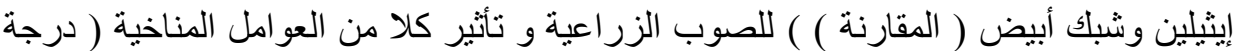
الحرارة والرطوبة النسبية وشدة الإضاءة ) فى توقيتات مختلفة خلال اليوم ( الثامنة صباحا و الو احدة ظهر ا و السادسة مساءاً ) مع التداخل بينهم على تقدم النمو الخضرى الخد الناتج بعد تطعيم شتنات أصول المانجو. فول الصول

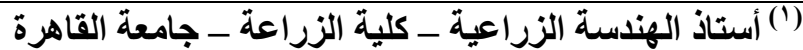

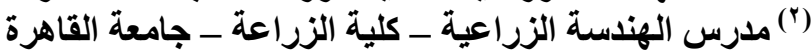

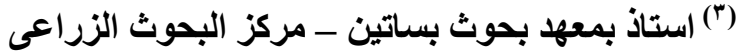


وبالتالى هناك تسع معاملات متداخلة يتم المقارنة بينهما وذللك فى ثلاث مكررات لكل معاملة

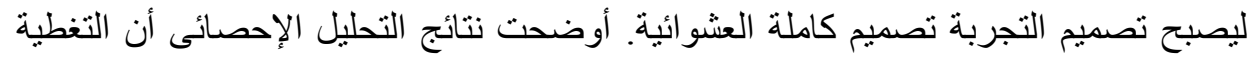

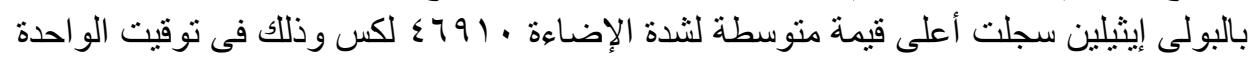
ظهراً بينما أقل قيمة متوسطة سجلت الإنها

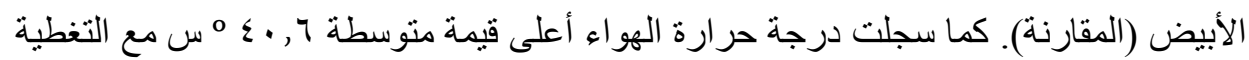

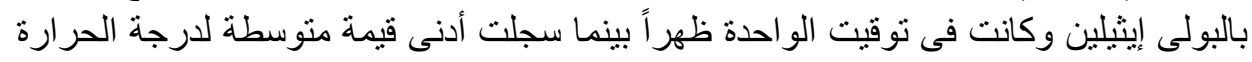

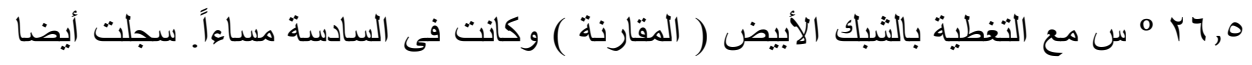

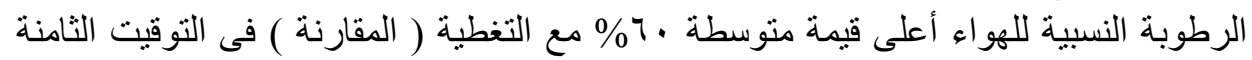

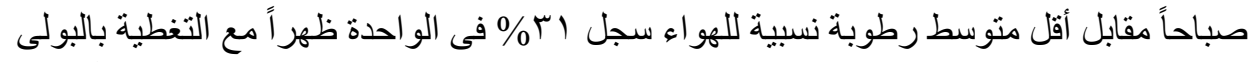

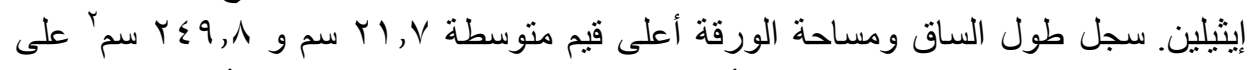

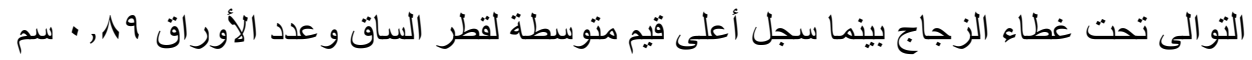

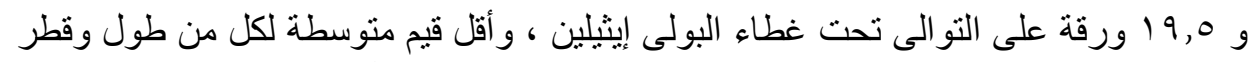

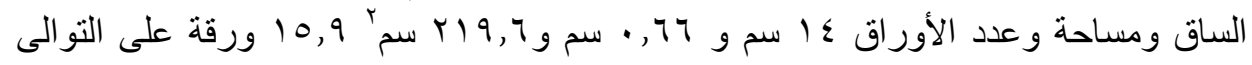

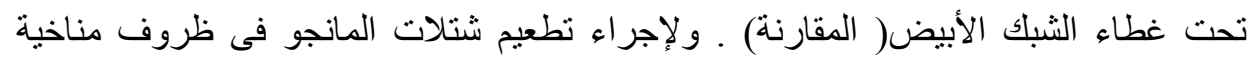

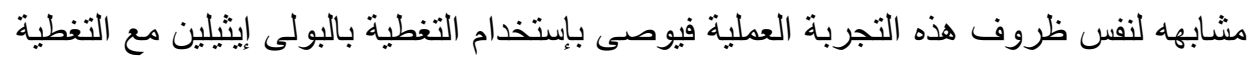

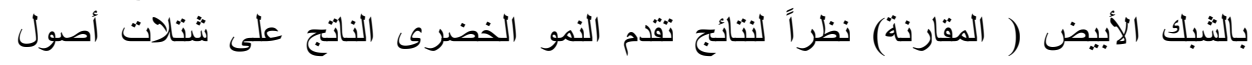

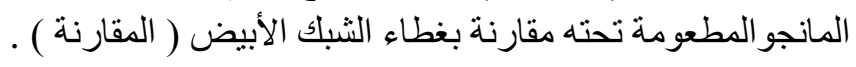

